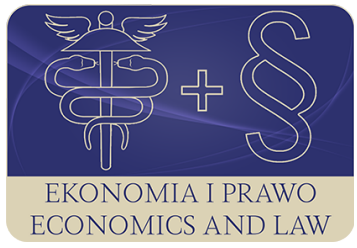

EKONOMIA I PRAWO. ECONOMICS AND LAW

Volume 20, Issue 2, June 2021

p-ISSN 1898-2255, e-ISSN 2392-1625

www.economicsandlaw.pl

ORIGINAL ARTICLE

received 21.10.2020; revised 20.06.2021; accepted 30.06.2021

Citation: Prokop, J. (2021). The role of patents in cartel stability. Ekonomia i Prawo. Economics and Law, 20(2), 401-412.

https://doi.org/10.12775/EiP.2021.024.

\title{
The role of patents in cartel stability
}

\section{JACEK PROKOP}

SGH Warsaw School of Economics, Collegium of World Economy, Department of Business Economics, al. Niepodległości 162, 02-554 Warszawa, Poland

$\square$ jacek.prokop@sgh.waw.pl

(D) orcid.org/0000-0001-5228-658X

\begin{abstract}
Motivation: Oligopolistic firms entering a collusive agreement often face the prisoner dilemma problem which makes such agreements inherently unstable. There has been a wide discussion in the literature on a variety of solutions to stabilize cartel arrangements. Only recently, it has been pointed out that patents could play an important role in cartel creation and functioning. However, there is a need for a formal modelling to better understand the role of patents in market competition.

Aim: In this paper, we consider the impact of patent rights on the competition of duopolists in the final product market. We assess the incentives of firms holding essential patents to create a cartel. Our main objective is to investigate the role of patents in cartel stability.

Results: Using game-theoretical approach, we show that it is beneficial for the patent-holding duoplists to form a cartel. Moreover, it is demonstrated that the existence of patents may help eliminate the prisoner dilemma problem faced by the participants of collusive agreement and significantly contribute to cartel stability. These conclusions

suggest that patents may play an important role in restricting market competition.
\end{abstract}

Keywords: patents; duopoly; collusion; cartel stability

JEL: L13; L41; O34

\section{Introduction}

Oligopolistic markets provide incentives for the firms to restrain competition by entering collusive agreements, or cartels. Firms may coordinate their output levels or pricing strategies to achieve higher profits. When all firms in a given industry create a cartel, they transform an oligopolistic market into a monopoly, 
which allows them to share the largest possible industry profit. However, for any cartel to survive, the collusion among firms must be stable.

There are two types of cartel stability: internal and external. A cartel is viewed as internally stable if it is not profitable for any member firm to defect from the collusive agreement. External stability means that it is not profitable for any non-member firm to join the existing collusion. A stable cartel is a collusion of firms which is both internally and externally stable.

There is plenty of evidence that cartels are short lived due to the prisoner's dilemma among the cooperating firms. ${ }^{1}$ Even though, the cooperation Pareto dominates cheating, there are strong incentives for the individual members to defect (compare, e.g., Pepall et al., 2014, pp. 351-352). However, there are still many cartels discovered by the antitrust authorities each year. ${ }^{2}$

Since cartel agreements are generally illegal, they cannot be enforced by courts. Therefore, any arrangement of that type needs some mechanism to sustain its stability. Identifying and understanding such mechanisms is crucial to deter cartel formation and to secure competitive environment.

There is a range of factors affecting the stability of collusion. ${ }^{3}$ Lipczynski et al. (2017, pp. 222-233) give a summary of the most important factors discussed by industrial organization researchers. In this paper we focus on the impact of patent rights on the competition of firms in the final product market. We consider a duopolistic industry in which each firm owns an essential patent needed for the production of the final output. Our main objective is to assess the incentives of firms holding patent rights to create a stable cartel.

The rest of this paper is organized as follows. In the next section, we give a brief overview of the literature on factors affecting the stability of cartels. The methods of analysis are discussed in section 3. Subsection 3.1 describes the non-cooperative game of firms competing according to Cournot-model of duopoly in the final product market. That is followed by the model of a fully cartelized industry in subsection 3.2. The results are presented in section 4. The last section contains the final conclusions and recommendations for further research.

${ }^{1}$ See, e.g., Levenstein, \& Suslow (2006, pp. 50-57) for the summary of findings on cartel duration. Also compare Harrington \& Wei (2017) for the duration of detected cartels.

${ }^{2}$ For an overview of cartel cases investigated by the EC see European Commission (2020).

3 For the analysis of the impact of cartel organizational features, macroeconomic fluctuations and industry structure on international cartel duration see, e.g., Levenstein, \& Suslow (2011). An interesting view is offered by Paha (2017) who shows that capacity investments can sometimes make collusion less valuable than competition. 


\section{Literature review}

It has been argued that by taking into account a dynamic framework of the oligopolistic competition, the firms escape the prisoner's dilemma. Repeated interactions of firms provide the incentives of long-run collusive profits and discourage cheating. The formal analysis of dynamic oligopoly has been conducted by applying the supergames (ee, e.g., Church \& Ware, 2000, pp. 331-340 or Tirole, 1997, pp. 245-247). Tirole (1997, pp. 246) demonstrates that collusion can be sustained in an infinite-horizon game as long as the discount factor is sufficiently high.

Green \& Porter (1984) demonstrated that the imperfections of information could destroy the collusion even in an infinite-horizon setting. When the behaviour of cartel members is not observable, the firms may not be sure about the causes of their unsatisfactory performance. The low profit may be a result of cheating, or a significant decline of market demand (compare also, Tirole, 1997, pp. 251-253, 262-265). That makes the cooperation of firms weaker.

Cartel agreements are lasting longer when there are only few firms in the industry and the market entry is restricted (see, e.g., Hay \& Kelly, 1974 or Pepall et al., 2014, pp. 375-376). In addition to the number of firms, an important role in cartel stability is played by the degree of homogeneity/heterogeneity. Compte et al. (2002) showed that firms with large production capacity have stronger incentives to cheat, because the ability of the smaller firms to retaliate is limited. They concluded that lesser asymmetry in production capacity favours collusion. Similar results in a different setting were obtained by Vasconelos (2005).

Another important factor affecting cartel stability is market demand. A rising demand contributes to stabilization of collusion, because the short-run benefits from cheating are smaller than the expected future gains. Rotemberg \& Saloner (1986) showed that collusion is hard to be sustained when firms face fluctuating demand. Harrington \& Skrzypacz (2007) pointed out that imperfect observability of competitors' prices could make it even harder to notice a sudden decline in demand.

An active antitrust policy to fight collusion has a significant impact on the stability of cartels. Among the most important tools applied by the governments are leniency programs introduced in the United States as well as in the European Union. The optimal program that minimizes the frequency with which collusion occurs was characterized by Harrington (2008). The impact of the leniency programs on preventing collusion has also been analysed by Aubert et al. (2006) and Spagnolo (2008). It was confirmed that the leniency programs contributed to a major destabilization of cartels.

The antitrust policy has not been uniformly applied in different countries. Choi \& Gerlach (2012) showed that in these circumstances competition of firms on several geographically different markets may encourage cooperation and helps stabilize collusion. A comprehensive discussion of the optimal competition policy was given by Harrington (2017). 
An interesting way to test antitrust law is offered by the experimental approach. Research by Bigoni et al. (2012) confirmed in a laboratory experiment that the implementation of leniency programs substantially increases the number of detected cartels through self-reporting of the participants. The experimental literature is relatively small, but it has already showed the leniency schemes constitute an effective tool in fighting collusive agreements.

The impact of patents on cartel stability was discussed by $\mathrm{Wu}$ (2019). It was shown that patent pool may stabilize a cartel of downstream producers. Wu (2019) argues that the vertical licensing relationship contributes to more effective monitoring of compliance with collusive agreements by licensees. However, no formal modelling was offered.

Recently, Karbowski (2020) offered a formal model of the relationship between patents and market collusion. He demonstrated that possibility of patenting may contribute to breaking the collusion of firms. Patents are shown to enable firms to leave the cartel without the risk of retaliation. Thus, it is a different role of patents than in $\mathrm{Wu}(2019)$.

\section{Methods}

In this paper, we propose a game-theoretical analysis of a duopoly market for a final product in which the two firms have an option to form a cartel. Each of them holds a patent to an essential element of the manufacturing process.

First, we focus on the analysis of the Cournot-type competition ${ }^{4}$ between duopolists with essential patents. A non-cooperative game with two identical firms as players is formulated and solved for the Nash equilibrium.

Second, we consider a model of a cartel formed by the duopolists who entered a patent pool. We investigate the stability of the cartel by analysing incentives to deviate from the collusive agreement. Two types of deviations are examined: a) price competition (undercutting), b) quantity competition (exceeding the cartel quota).

Finally, by comparing the benefits of deviations to the collusive profits, we conclude about the stability of the cartel arrangement when patent rights are considered.

\subsection{Cournot duopolists with essential patents}

Consider an industry composed of two firms denoted 1 and 2 . The firms compete in the final product market by supplying a homogenous good. The market is characterized by an inverse demand function of following linear type:

$$
p=a-q_{1}-q_{2},
$$

${ }^{4}$ A different setting for the analysis of cartel stability is a price leadership model discussed by many researchers, e.g., Diamantoudi (2005). 
where $p$ denotes the market price of the final product, $q_{i}$ is the output supplied by firm $i(i=1,2)$, and $a$ is a positive parameter.

We assume that the technology used in the production process consists of two important elements, denoted A and B. Both of them are needed to manufacture the final product. The element $\mathrm{A}$ is patented by firm 1 , and the patent rights to element B is held by firm 2.

The total costs of production for the firm $i$ is determined by the following linear function:

$$
\left(c+w_{j}\right) q_{i},
$$

where $c$ is a given cost parameter and $w_{j}$ is the price paid to company $j(j \neq i)$ for the patent rights. We assume that $c<a$ and the entry barriers to this industry are too high for any potential entry to occur.

We consider a game that consists of two stages. In the first stage, each firm $i$ sells its patent rights to the other firm in the industry at the price $w_{i}$. In the second stage, the firms compete in the final product market by choosing their level of output (Cournot model of duopoly).

The profit of firm $i$ could be presented in the following form:

$$
\pi_{i}=\left(a-q_{i}-q_{j}-c-w_{j}\right) q_{i}+w_{i} q_{j} .
$$

We use backward induction to find the equilibrium of the above game by first considering the second stage. From the first order conditions for profit maximization with respect to the level of output $q_{i}$ :

$$
\frac{\partial \pi_{i}}{\partial q_{i}}=a-c-2 q_{i}-q_{j}-w_{j}=0
$$

we obtain the profit-maximizing supply of firm $i$ :

$$
q_{i}=\frac{1}{3}\left(a-c+w_{i}-2 w_{j}\right) .
$$

The levels of production $q_{1}$ and $q_{2}$ given by (5) constitute the Cournot-Nash equilibrium for given level of prices charged by firms for their patent rights, $w_{1}$ and $w_{2}$.

After substituting (5) into the expression (3), we obtain the profits of each of the firms, $\pi_{1}$ and $\pi_{2}$ as a function of patent royalties $w_{1}$ and $w_{2}$ :

$$
\pi_{i}\left(w_{i}, w_{j}\right)=\frac{1}{9}\left[(a-c)^{2}+\left(5 w_{i}-4 w_{j}\right)\left(a-c-w_{i}-w_{j}\right)\right] .
$$

In the first stage, when the firms simultaneously and independently set their prices for the patent rights, the Nash equilibrium strategies are obtained as a solution to the system of two equations in two unknowns $w_{1}$ and $w_{2}$ : 


$$
\frac{\partial \pi_{i}}{\partial w_{i}}=\frac{1}{9}\left(5 a-5 c-10 w_{i}-w_{j}\right)=0
$$

By solving the above system, we obtain:

$$
w_{i}^{*}=\frac{5(a-c)}{11} \text {. }
$$

Substituting $w_{i}^{*}$ for $w_{i}$ in (5) and (6) we arrive at the equilibrium production level of each firm:

$$
q_{i}^{*}=\frac{2(a-c)}{11},
$$

and their equilibrium levels of profit:

$$
\pi_{i}^{*}=\frac{14}{121}(a-c)^{2} .
$$

From (1) and (9), the equilibrium market price of the final product offered by the competing firms equals to:

$$
p^{*}=\frac{(7 a+4 c)}{11} \text {. }
$$

Now, we move on to discuss a collusive agreement between the duopolists in this industry.

\subsection{Fully cartelized industry}

Consider the case of an industry cartel formed by both firms. We assume that the demand function as well as the costs are the same as in the previous section of this paper. The firms in the cartel form a patent pool which allows them not to pay any royalties for any level of production not exceeding $\frac{a-c}{4}$, as long as the supply of each of the firms is positive. For each unit of output in excess of that level, the firm must pay the royalties determined by the noncooperative Cournot competition in the market, i.e., $w_{i}^{*}=\frac{5(a-c)}{11}$. The same patent price per unit of supply must be paid by the firm producing positive output, when its competitor observes no sales.

On the final product market, the firms decide about the levels of output $q_{1}$ and $q_{2}$ to maximize joint profit: 


$$
\pi=\pi_{1}+\pi_{2}=\left(a-q_{1}-q_{2}-c\right) q_{1}+\left(a-q_{2}-q_{1}-c\right) q_{1} .
$$

The first order condition for profit maximization is as follows:

$$
\frac{\partial \pi}{\partial q_{1}}=a-c-2 q_{1}-2 q_{2}=0 .
$$

Since we focus on the symmetric equilibrium, we have $q_{1}=q_{2}$. Thus from (13), we obtain the equilibrium output of each cartel member:

$$
\bar{q}_{i}=\frac{a-c}{4} .
$$

Substituting (14) for $q_{i}$ into the inverse demand function given by (1), we arrive at the symmetric equilibrium price of the final product supplied by the cartel:

$$
\bar{p}=\frac{a+c}{2} .
$$

From (12) and (14), we calculate the total cartel profit in the equilibrium:

$$
\bar{\pi}=\frac{(a-c)^{2}}{4} \text {. }
$$

In the case of both firms forming an industry cartel, each of them earns:

$$
\bar{\pi}_{1}=\bar{\pi}_{2}=\frac{1}{2} \bar{\pi}=\frac{(a-c)^{2}}{8} \text {. }
$$

Comparing the cartel profit of each firm given by (17) and the non-cooperative profit given by (10), we clearly see that it pays for both firms to enter the collusive agreement.

In the next step, it is important to check the stability of the above cartel. In the case of no patent rights, if firm $i$ believes that firm $j$ is going to obey the collusive agreement by sticking to the output $\bar{q}_{j}=\frac{a-c}{4}$, then firm $i$ should produce an output that is a best response to $\bar{q}_{j}=\frac{a-c}{4}$. Firm i's profit is given by:

$$
\pi_{i}=\left(a-q_{i}-\bar{q}_{j}-c\right) q_{i}=\left(a-q_{i}-\frac{a-c}{4}-c\right) q_{i} .
$$


From the first order conditions for profit maximization:

$$
\frac{\partial \pi_{i}}{\partial q_{i}}=\frac{3(a-c)}{4}-2 q_{i}=0,
$$

we obtain firm i's optimal output:

$$
q_{i}=\frac{3(a-c)}{8}>\bar{q}_{i}=\frac{a-c}{4}
$$

and firm i's profit:

$$
\pi_{i}=\frac{9(a-c)^{2}}{64}>\bar{\pi}_{i}=\frac{(a-c)^{2}}{8} .
$$

It means that the cartel will not be stable, if patent rights are neglected.

Now, let us take into account the issue of patents. We consider two possibilities depending on the assumptions regarding the type of market competition in place when a firm attempts to deviate from the cartel agreement.

First, we focus on a possibility of price competition of Bertrand type. In that case, a slight price undercutting by firm $i$ by charging $\tilde{p}_{i}=\bar{p}-\varepsilon=\frac{a+c}{2}-\varepsilon$, where $\varepsilon$ is a small positive number, leads to capturing the entire market demand, i.e., $\tilde{q}_{i} \approx \frac{a-c}{2}$, leaving firm $j$ with no demand, i.e. $\tilde{q}_{j}=0$. Breaking the cartel agreement will cause the need for the firm $i$ to make payments for the patent rights of company $j$. Then, the net profit of firm $i$ is:

$$
\tilde{\pi}_{i}=\left(a-\tilde{q}_{i}-c-\tilde{w}_{j}\right) \tilde{q}_{i} \approx\left(a-\frac{a-c}{2}-c-\frac{5(a-c)}{11}\right) \frac{(a-c)}{2}=\frac{(a-c)^{2}}{44} .
$$

Firm $j$ has no sale's revenue but it obtains royalty transfers equal to

$$
\tilde{w}_{j} \tilde{q}_{i} \approx \frac{5(a-c)}{11} \cdot \frac{a-c}{2}=\frac{5(a-c)^{2}}{22} .
$$

Comparing the profit to firm $i$ from cheating given by (22) to that firm's profit in the cartel given by (17), we observe that the latter is bigger than the former, i.e.,

$$
\tilde{\pi}_{i}=\frac{(a-c)^{2}}{44}<\bar{\pi}_{i}=\frac{(a-c)^{2}}{8} .
$$


Thus, we may conclude that it doesn't pay for the firms to deviate from the cartel arrangement by undercutting the collusive price. That conclusion is different from the case of a typical collusion when the patent rights are not considered.

Another possibility is quantity competition. If firm $i$ believes that firm $j$ is going to obey the cartel agreement by sticking to the output $\bar{q}_{j}=\frac{a-c}{4}$, then firm i's best course of action is to check whether it pays to increase production above $\bar{q}_{j}=\frac{a-c}{4}$.

For $q_{i}>\frac{a-c}{4}$, firm i's profit is given by:

$$
\begin{aligned}
& \pi_{i}=\left(a-q_{i}-q_{j}-c\right) q_{i}-w_{j}\left(q_{i}-\frac{a-c}{4}\right)= \\
& =\left(a-q_{i}-\frac{a-c}{4}-c\right) q_{i}-\frac{5(a-c)}{11}\left(q_{i}-\frac{a-c}{4}\right) .
\end{aligned}
$$

Taking the derivative of (25) with respect to $q_{i}$, we obtain:

$$
\frac{\partial \pi_{i}}{\partial q_{i}}=\frac{13(a-c)}{44}-2 q_{i} \text {. }
$$

Observe that for $q_{i}>\frac{a-c}{4}$, the derivative in (26) is negative, i.e. $\frac{\partial \pi_{i}}{\partial q_{i}}=\frac{13(a-c)}{44}-\frac{2(a-c)}{4}=-\frac{9(a-c)}{44}<0$. It means that increasing $q_{i}$ above $\frac{a-c}{4}$ reduces firm i's profit. Thus, it doesn't pay for the firm $i$ to increase the output above the cartel quota.

It should also be noticed that given our assumption about the patent pool arrangement, no firm is interested in reducing production given that the competitor sticks to the cartel agreement. Therefore, also in the case of quantity competition, we conclude that it doesn't pay for the firms to deviate from the cartel arrangement by changing the production level. 


\section{Results}

The analysis of the previous section showed that the duopolists holding essential patents in the production process are better off by forming a cartel with a patent pool. That result is identical to the case of duopolists without patent rights who are also benefiting from collusion rather than noncooperative behaviour of Cournot- or Bertrand-type.

However, further considerations of possible deviations of cartel members from a collusive agreement demonstrated that it is not profitable for the participating firms to cheat when the patent rights are taken into account. The obtained stability of the cartel arrangement may be viewed as quite strong, since the firms have no incentives to undercut prices or to produce above the cartel quota.

\section{Conclusion}

Using game-theoretical approach, we showed that it is beneficial for the patent-holding duopolists to form a cartel. Moreover, we demonstrated that the existence of patents may help eliminate the prisoner dilemma problem faced by the participants of collusive agreement and significantly contribute to cartel stability. These conclusions suggest that patents may play an important role in restricting market competition. Thus, they should be under scrutiny by the antitrust authorities.

The results of this paper that patents contribute to cartel stability are similar to those provided by $\mathrm{Wu}(2019)$ in somewhat different framework. However, it should be noticed that our conclusions are different from the case of collusion when the patent rights are not considered. Also, the results of this article show a different way in which patents may affect the behaviour of cartel members then the considerations provided in Karbowski (2020).

Clearly, further research is necessary to give the final assessment of the role of patents in cartel stability.

\section{References}

Aubert, C., Kovacic, W., \& Rey, P. (2006). The impact of leniency and whistle-blowing programs on cartels. International Journal of Industrial Organization, 24(6), 1241-1266. https://doi.org/10.1016/j.ijindorg.2006.04.002.

Bigoni, M., Fridolfsson, S.-O., Le Coq, C., \& Spagnolo G. (2012). Fines, leniency, and rewards in antitrust. The RAND Journal of Economics, 43(2), 368390. https://doi.org/10.1111/j.1756-2171.2012.00170.x.

Choi, J.P., \& Gerlach, H. (2012). International antitrust enforcement and multimarket contact. International Economic Review, 53(2), 635-658. https:// doi.org/10.1111/j.1468-2354.2012.00695.x. 
Church, J., \& Ware, R. (2000). Industrial organization: a strategic approach. McGraw-Hill.

Compte, O., Jenny, F., \& Rey, P. (2002). Capacity constraints, mergers and collusion. European Economic Review, 46(1), 1-29. https://doi. org/10.1016/S0014-2921(01)00099-X.

Diamantoudi, E. (2005). Stable cartels revisited. Economic Theory, 26(4), 907921. https://doi.org/10.1007/s00199-004-0550-0.

European Commission. (2020). Cartels: cases. Retrieved 17.10.2020 from https://ec.europa.eu/competition/cartels/cases/cases.html.

Green, E.J., \& Porter, R.H. (1984). Noncooperative collusion under imperfect price information. Econometrica, 52(1), 87-100. https://doi. $\operatorname{org} / 10.2307 / 1911462$.

Harrington, J.E. (2008). Optimal corporate leniency programs. The Journal of Industrial Economics, 56(2), 215-246. https://doi. org/10.1111/j.1467-6451.2008.00339.x.

Harrington, J.E. (2017). The theory of collusion and competition policy. MIT Press.

Harrington, J.E., \& Skrzypacz, A. (2007). Collusion under monitoring of sales. The RAND Journal of Economics, 38(2), 314-331. https://doi. $\operatorname{org} / 10.1111 /$ j.1756-2171.2007.tb00070.x.

Harrington, J.E., \& Wei, Y. (2017). What can the duration of discovered cartels tell us about the duration of all cartels. The Economic Journal, 127(604), 1977-2005. https://doi.org/10.1111/ecoj.12359.

Hay, G.A., \& Kelly, D. (1974). An empirical survey of price fixing conspiracies. Journal of Law and Economics, 17(1), 13-38. https://doi.org/10.1086/466782.

Karbowski, A. (2020). A note on patents and leniency. Gospodarka Narodowa, 301(1), 97-108. https://doi.org/10.33119/GN/116615.

Levenstein, M.C., \& Suslow, V.Y. (2006). What determines cartel success. Journal of Economic Literature, 44(1), 43-95. https://doi. org/10.1257/002205106776162681.

Levenstein, M.C., \& Suslow, V.Y. (2011). Breaking up is hard to do: determinants of cartel duration. Journal of Law and Economics, 54(2), 455-492. https://doi.org/10.1086/657660.

Lipczynski, J., Wilson, J.O.S., \& Goddard, J. (2017). Industrial organization: competition, strategy and policy. Pearson.

Paha, J. (2017). The value of collusion with endogenous capacity and demand uncertainty. Journal of Industrial Economics, 65(3), 623-653. https://doi. org/10.1111/joie.12143.

Pepall, L., Richards, D.J., \& Norman, G. (2014). Industrial organization: contemporary theory and empirical applications. Wiley.

Rotemberg, J.T., \& Saloner, G. (1986). A supergame-theoretic model of price wars during booms. The American Economic Review, 76(3), 390-407.

Spagnolo, G. (2008). Leniency and whistle-blowers in antitrust. In P. Buccirossi (Ed.), Handbook of antitrust economics (pp. 259-304). MIT Press.

Tirole, J. (1997). The theory of industrial organization. MIT Press. 
Vasconelos, H. (2005). Tacit collusion, cost asymmetries, and mergers. The RAND Journal of Economics, 36(1), 39-62.

$\mathrm{Wu}, \mathrm{W}$. (2019). Managing cartels through patent pools. The Antitrust Bulletin, 64(3), 457-473. https://doi.org/10.1177/0003603X19863592.

\section{Acknowledgements}

Author contributions: author has given an approval to the final version of the article.

Funding: this research was undertaken as part of the Dynamics of market structure project and was fully funded by the SGH Warsaw School of Economics, Collegium of World Economy, Department of Business Economics statutory sources. 